\title{
Total maximum daily loads of beton reservoir, Gunungkidul Regency, Indonesia during the rainy season
}

\author{
Febby Firizqi and Margaretha Widyastuti* \\ Department of Environmental Geography, Faculty of Geography, Universitas Gadjah Mada, 55281 Yogyakarta Special Region \\ Indonesia
}

\begin{abstract}
A total maximum daily load (TMDL) is an integrated mechanism to maintain water body to meet the water quality standards of its designated uses. This research was intended to determine the TMDL of Beton Reservoir, a structure built to regulate the water discharge of Beton karst spring in Gunungkidul, Indonesia, especially during the rainy season. The TMDL calculation referred to the Regulation of the Minister of State for Environment No. 28 of 2009 on TMDLs of Lakes and/or Reservoirs that required a calculation of morphological and hydrological characteristics, and water quality to meet Class II standard issued in the Regulation of the Governor of the Special Region of Yogyakarta No. 20 of 2008. The results showed that Beton Reservoir had a total volume of $22586.83 \mathrm{~m}^{3}$, a surface area of $18673.12 \mathrm{~m}^{2}$, and a depth of averagely $1.21 \mathrm{~m}$ and released water at a rate of $0.48 \mathrm{~m}^{3} \mathrm{~s}^{-1}$. From the perspective of quality, the TSS and DO of its water had exceeded the standards, whereas the other parameters: temperature, TDS, $\mathrm{pH}$, BOD, COD, total $\mathrm{PO}_{4}$, and $\mathrm{NO}_{3}$ were within their allowable presence in the water. Based on TMDLs for TSS, DO, BOD, COD, total $\mathrm{PO}_{4}$, and $\mathrm{NO}_{3}$, the Beton Reservoir can no longer accommodate TSS and $\mathrm{NO}_{3}$ while continuing to meet the standards for these pollutants. High levels of TSS and $\mathrm{NO}_{3}$ are attributable to the agricultural activities taking place on the catchment and the flow concentration typical of karst regions.
\end{abstract}

\section{Introduction}

Karst is a terminology used to describe landscapes that develop in soluble rocks and are characterized by the development of caves and subterranean hydrological systems [1]. Karst thereby has a distinctive hydrological feature, that is, a conduit development system due to the rock dissolution process [2]. Its hydrological flow systems are differentiated into diffuse, fissure, and conduit. A conduit system has a rapid turbulent flow response [3] that, if connected to this system, a karst spring will also have a rapid response to a high-intensity rain event [4].

Karst catchments evolve through a complex hydrological and transportation process; thus, they are severely susceptible to hydrological problems and water quality deterioration [5]. Prior scholars contend that agriculture is one of the biggest sources of pollution karst waters [6-8]. Harmful byproducts of farming practices enter subterranean systems through sinkholes and sinking streams in catchments and are transported to a resurgence point [4]. Many agricultural activities apply fertilizers and pesticides containing nitrogen and phosphorus. Prolonged soil-water contact allows runoff to carry these nutrients, which at certain levels, can be detrimental to waters [7].

Pollution, along with the subsequent water quality deterioration, can be in the form of a point source or a non-point source. A total maximum daily load (TMDL) is an approach used in water pollution control based on

\footnotetext{
* Corresponding author: mwiwik@ugm.ac.id
}

the source of pollutants and water quality [9]. TMDL is defined as the maximum amount of a pollutant that a body of water can receive without exceeding the water quality standards and the total waste load or load allocations [10].

This research determined the TMDL of Beton Reservoir that is connected to a karst conduit system, particularly during the rainy season. It also sought to identify morphometric and hydrological characteristics and the water quality of the reservoir as a requirement in the TMDL calculation. This research is essential in that it discusses how agricultural practices and karst hydrological characteristics impacting springs can affect the overall water quality of Beton Reservoir. Because the catchment of the reservoir is used most largely for dry-cultivated farmland, the computed pollution loads focused on parameters representative of reduced water quality due to farming practices. Meanwhile, the TMDL calculations for lake and reservoir waters referred to the Regulation of the Minister of State for Environment No. 28 of 2009 [11]. Here, water quality condition and hydrological and morphological influence on the ability of Beton Reservoir to carry pollution loads were taken into considerations in the calculation [12].

\section{Research area}

Beton Reservoir is located in Umbulrejo Village, Ponjong District, Gunungkidul Regency, with an indicative catchment area of 1.87 ha. Geographically, it 
extends from $7^{\circ} 56^{\prime} 58^{\prime \prime} \mathrm{S}$ to $7^{\circ} 57^{\prime} 5^{\prime \prime}$ and from $110^{\circ}$ $43^{\prime} 31^{\prime \prime}$ to $110^{\circ} 43^{\prime} 40^{\prime \prime} \mathrm{E}$. The water is sourced from Beton Spring, whose catchment covers five villages in Ponjong District and is connected to two sinkholes (Sawahombo and Sawahan Seropan) and two springs (Sriti and Selonjono)-typical features of conduit development in karst regions [13], which is situated in farmland-dominated landuse. Physiographically, Beton Reservoir is situated at Gunungsewu Karst Area [14]. The hydrogeological features of its surroundings (Ponjong District) include the emergence of springs as a product of conduit networks in karst hydrological system [15]. Beton Spring is perennial, with conduit as its dominant flow component and some remaining characteristics of a diffuse release system. Time to peak (highest discharge) is reached in two hours after rainfall, while the mean recession time is up to $33 \mathrm{~h}$ [16]. On average, karst regions in Gunungkidul Regency receive $1625 \mathrm{~mm}$ to $2125 \mathrm{~mm}$ of rainfall per year. At this rate, high rain input can substantially control the karstification process [17].

\section{Methods}

\subsection{Data collection technique}

\subsubsection{Morphological and hydrological characterization}

In this research, the observed morphological and hydrological situations of the reservoir concentrated on the parameters used in the TMDL calculation, namely surface area, volume, discharge, average depth, and water flushing rate [11]. The required base data were depth and outflow discharge. Depths were estimated using an echo sounder and depth finder at every $10 \times$ $10 \mathrm{~m}^{2}$ grid of surface area. The results were then interpolated into depth contours or bathymetric maps in the ArcGIS program. At the outlet channel, the speed of the water flow was measured using a current meter, and the discharge was calculated by the mean section method.

After the bathymetric map was completed, it was used to compute the surface area $\left(\mathrm{m}^{2}\right)$ digitally in the ArcGIS program. Volume (V) was the sum of the entire volumes calculated for every depth stratum, from the surface to the maximum depth. It was calculated using a parabolic approach and the equation below (1):

$$
V=\sum_{\mathrm{i}=0}^{\mathrm{n}} \frac{\mathrm{lc}}{3}\left(\mathrm{~A}_{\mathrm{i}}+\mathrm{A}_{\mathrm{i}+1} \sqrt{\mathrm{A}_{\mathrm{i}} \times \mathrm{A}_{\mathrm{i}+1}}\right)
$$

where $\mathrm{V}=$ water volume of reservoir $\left(\mathrm{m}^{3}\right), \mathrm{lc}=$ contour interval $(\mathrm{m}), \mathrm{A}_{\mathrm{i}}=$ surface area of contour $\mathrm{i}\left(\mathrm{m}^{2}\right)$, and $\mathrm{n}$ $=$ number of contours.

Average depth $(\overline{\mathrm{Z}})$ was mathematically expressed as a ratio of volume $(\mathrm{V})$ to surface area $\left(\mathrm{A}_{0}\right)$ :

$$
\overline{\mathrm{Z}}=\frac{\mathrm{V}}{A_{0}}
$$

The outflow discharge (Q) was measured directly in the field using a current meter and calculated based on the Indonesian National Standard (SNI) for the mean section method [19]. Afterward, these data were divided by volume (V) to produce water flushing rates $(\rho)$. The formulas for discharge and water flushing rate calculations were as follows:

$$
\begin{gathered}
\mathrm{Q}_{\mathrm{o}}=\mathrm{A}_{\mathrm{p}} \times \mathrm{v} \\
\mathrm{v}=\mathrm{aN}+\mathrm{b} \\
\rho=\frac{V}{Q}
\end{gathered}
$$

where $\mathrm{Q}=$ outflow discharge of the reservoir $\left(\mathrm{m}^{3} / \mathrm{s}\right)$, $A_{p}=$ wetted surface area $\left(\mathrm{m}^{2}\right), \mathrm{v}=$ flow velocity $(\mathrm{m} / \mathrm{s}), \mathrm{N}$ = rotation rate $(\mathrm{N}=\mathrm{R} / \mathrm{T}), \mathrm{R}=$ number of rotations of propeller, $\mathrm{T}=$ elapsed time (duration of one measurement), $a$ and $b=$ coefficients based on the current meter calibration equation.

\subsubsection{Water quality analysis}

Sampling for water quality analysis was conducted at the beginning of the rainy season, January 2020. The time selection referred to the known optimal water volume and water discharge at the outlet of the reservoir. In an attempt to observe any temporal variations, composited water quality data in the dry season was obtained from previous research that gathered the data in May 2019 [20]. The sampling locations, selected by a purposive sampling method, were distributed at the inlet, middle, and outlet of the reservoir and the entry points of pollution loads (Figure 1). Water sampling at each of these points followed the Indonesian National Standard (SNI), which requires the water samples at the surface and bottom of the reservoir to be composited (mixed).

Temperature, conductivity, Total Dissolved Solid (TDS), and $\mathrm{pH}$ were measured directly in the field using a water quality checker. In the laboratory, the water samples were further tested for their Total Suspended Solid (TSS), Dissolved Oxygen (DO), Biochemical Oxygen Demand (BOD), Chemical Oxygen Demand (COD), nitrates $\left(\mathrm{NO}_{3}\right)$, total phosphate $\left(\mathrm{PO}_{4}\right)$, and total coliform levels. These water samples are the composite of samples taken at specific depths. Then, the parameter values were observed side by side with the Class II water quality standard (WQS) issued in the Regulation of the Governor of the Special Region of Yogyakarta (SRY) No. 20 of 2008 to determine whether or not they supported one or more designated uses of the reservoir [21], analyze the spatial-temporal variation of the water quality, and calculate the TMDL.

Furthermore, the analysis was intended to confirm the presumption that pollutants found in the reservoir came from agricultural land in its catchment. Unstructured interviews with farmers (i.e., respondents working in the catchment area) provided details on types of fertilizers and intensities of fertilization. 
Agricultural fields in Sawahombo (Tambakromo Village) and Sawahan Seropan (Sawahan) were selected because they were directly connected to of area of the reservoir $\left(\mathrm{mg} / \mathrm{m}^{2}\right.$.year $), \mathrm{La}=\mathrm{TMDL}$ for $P a$ in the entire reservoir (kg/year), and $\mathrm{R}=$ total amount of $P a$ left in the sediments sinkholes that led to Beton Spring.

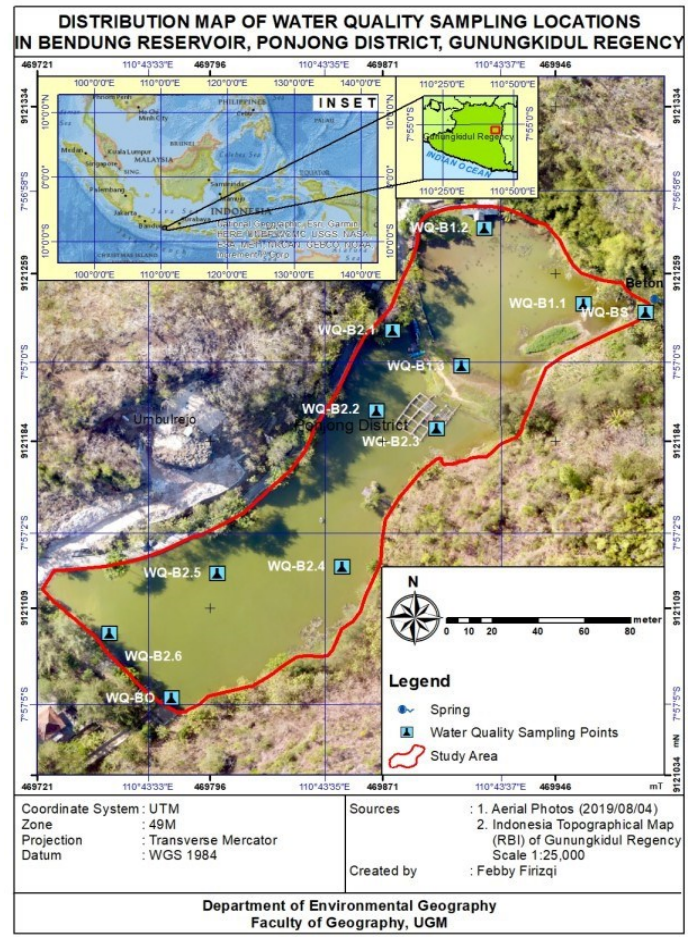

Fig. 1. Distribution map of water quality sampling locations

\subsection{Total maximum daily load (TMDL) calculation}

In this study, TMDL calculations were developed for TSS, DO, BOD, COD, nitrate, and total phosphate. The Regulation of the Minister of State for Environment No. 28 of 2009 partitions its calculation into three stages, namely morphological and hydrological characterization, derivation of waste load or load allocations, and TMDL analysis, as explained below.

$$
\begin{gathered}
{[\mathrm{Pa}] \mathrm{STD}=[\mathrm{Pa}] \mathrm{i}+[\mathrm{Pa}] \text { cat }+[\mathrm{Pa}] \mathrm{d}} \\
{[\mathrm{Pa}] \mathrm{d}=[\mathrm{Pa}] \mathrm{STD}-[\mathrm{Pa}] \text { cat }-[\mathrm{Pa}] \mathrm{i}} \\
\mathrm{L}=\Delta[\mathrm{Pa}] \mathrm{d} \check{z}=\frac{\rho}{(1-R)} \\
R=\frac{1}{\left(1+0.747 \rho^{0.507}\right)} \\
L=\frac{\mathrm{L} \times \mathrm{A}}{100}=\Delta[\mathrm{Pa}] \mathrm{dA} \check{Z}=\frac{\rho}{(1-R)}
\end{gathered}
$$

where $[\mathrm{Pa}]_{\mathrm{STD}}=$ maximum level of $P a$ according to water quality standard or class of water $\left(\mathrm{mg} / \mathrm{m}^{3}\right),[\mathrm{Pa}]_{\mathrm{i}}$ = the actual or observed amount of $\mathrm{Pa}\left(\mathrm{mg} / \mathrm{m}^{3}\right)$, [Pa]cat $=$ allowable load of $P a$ generated by the catchment (or load allocation, in $\left.\mathrm{mg} / \mathrm{m}^{3}\right)$, $[\mathrm{Pa}] \mathrm{d}=$ allowable load of $P a$ generated by activities in the reservoir (or waste load allocation, in $\left.\mathrm{mg} / \mathrm{m}^{3}\right), \mathrm{L}=$ TMDL for $P a$ per unit

\section{Results and discussion}

\subsection{Morphological and hydrological conditions of beton reservoir}

Morphometry describes the physical characteristics of a body of water and can be visually presented in a bathymetric map [22]. The bathymetric map of Beton Reservoir (Figure 2) can help to identify advanced morphometry, both on and under the water surface. It shows that the maximum depth of the reservoir is 2.6 meters, found in two locations: (1) right after the Beton Bridge and (2) in the middle of the larger part of the reservoir. The total surface area of the reservoir is $18673.12 \mathrm{~m}^{2}$.

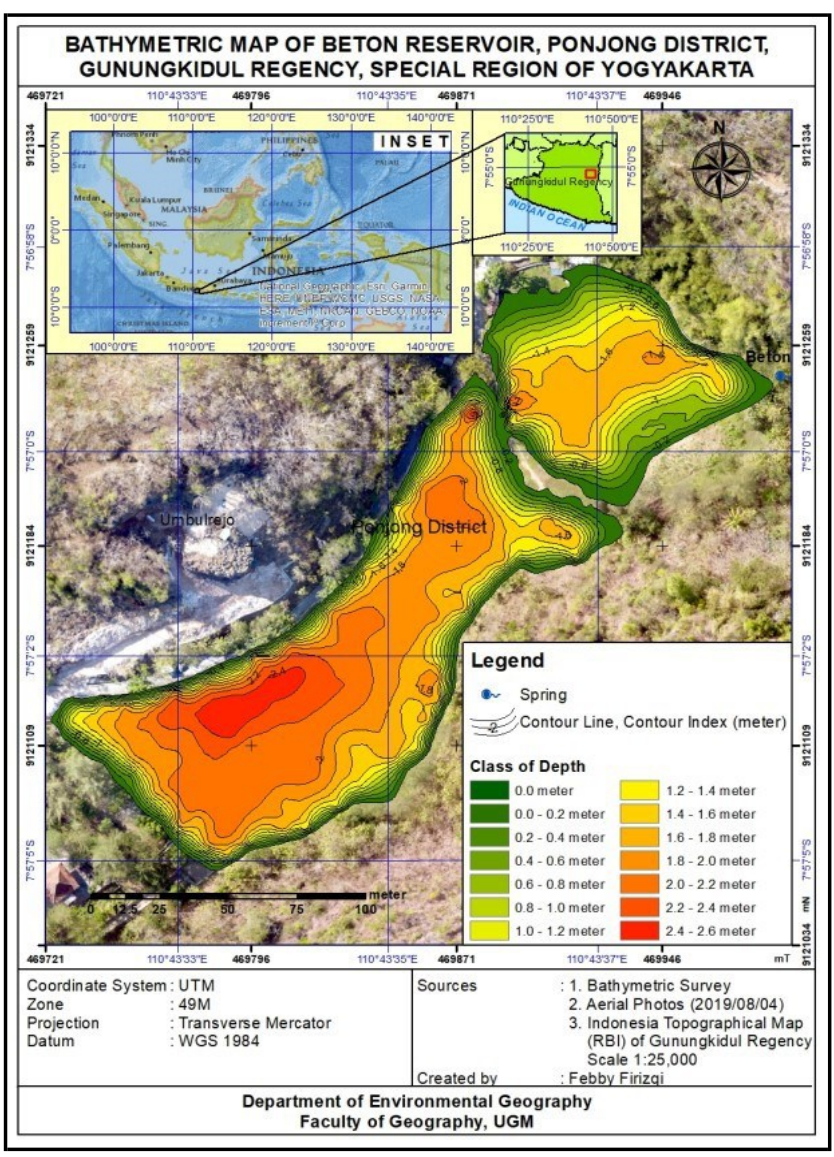

Fig. 2. The bathymetric map of beton reservoir

The volume of this water body, constructed from data on surface area per contour, is $22586.83 \mathrm{~m}^{3}$, which classifies the reservoir as very small-sized [23]. The Beton Reservoir is averagely $1.21 \mathrm{~m}$ deep, which is categorically shallow. With a shallow dimension, waters might have low stratification stability, and the water contents are easily stirred or agitated.

In the rainy season, the outflow discharges at the two outlets are $0.48 \mathrm{~m}^{3} \mathrm{~s}^{-1}$ or $15016478.2 \mathrm{~m}^{3} \mathrm{yr}^{-1}$, which is categorically large for the size of the Beton Reservoir. It far exceeds the discharge of other artificial lakes with larger volumes in Indonesia [2426]. 
The high spring discharge in the rainy season is a known factor of such a large outflow rate at this reservoir. The Beton Spring discharge increases most significantly in the rainy season due to its conduit characteristic. Water quickly fills the very small-sized reservoir, and, more often than not, the capacity is overflowed.

The water flushing took place twice a day or equivalent to 665 times a year. At this high frequency, flushing can circulate the water so that the pollution loads can be discharged or removed from the reservoir, increasing its TMDL. However, a high rate of water flushing can, in turn, cause siltation. Water sources from the catchment continue to transport and deposit sediments to the reservoir, which reduces the volume of water. It is evidenced by the average depth of the reservoir, which is only $1.21 \mathrm{~m}$, even though the bathymetric map shows a maximum depth of $2.6 \mathrm{~m}$.

\subsection{Water quality of the beton reservoir}

\subsubsection{Temperature}

Temperature is a physical parameter of water quality that can be directly gauged in the field. From the upper section in the northeast to the lower end in the south, the water showed varying temperatures, with an average of $26.95{ }^{\circ} \mathrm{C}$. In the rainy season, the water temperature ranged from $26.4{ }^{\circ} \mathrm{C}$ to $27.5{ }^{\circ} \mathrm{C}$ (Figure 3) but tended to hover around $29.2{ }^{\circ} \mathrm{C}$ in the dry season. At this range, the temperature meets the water quality standard because calculations using the Mock equation revealed that the air local air temperatures were between $25.4{ }^{\circ} \mathrm{C}$ and $26.3{ }^{\circ} \mathrm{C}$ during the rainy season and around $26.4{ }^{\circ} \mathrm{C}$ in the dry season.

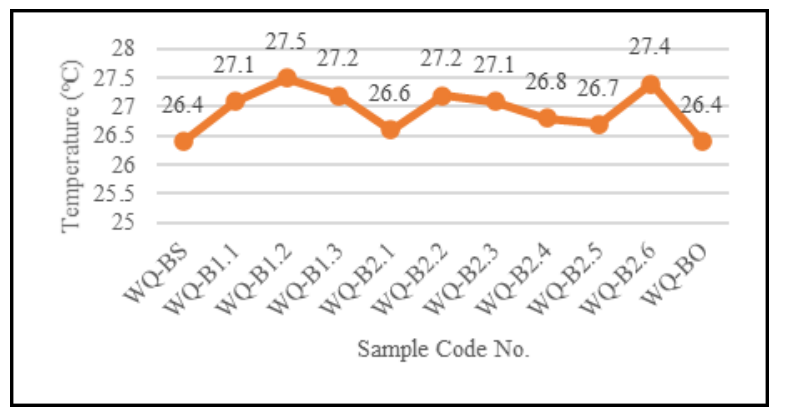

Fig. 3. Water temperatures of beton reservoir in rainy seasons

The lowest temperature was measured at the inlet (WQ-BS) and outlet (WQ-BO). During the rainy season, the temperature of the inflow did not significantly differ from that of the outflow. A high volume of inflow causes mixing and, in the middle of the reservoir, it will adjust to the condition of the water body. The highest temperatures were recorded at WQB1.2 and WQ-B2.6 because these points were open and shallow waters. Temperature differences can also be caused by sampling that is not carried out at the same time. Temporally, a decrease in temperature during the rainy season is attributable to climatic factors.

\subsubsection{Conductivity}

Electrical conductivity (EC) generally describes the concentration of dissolved ions in waters. While the EC of the Beton Reservoir varied between 282 and $325 \mu \mathrm{S} / \mathrm{cm}$ in the rainy season, it had a composite EC of $511 \mu \mathrm{S} / \mathrm{cm}$ in the dry season. It indicates that rainwater controls the concentration of ions and minerals in the water. Low EC is easily found in waters receiving high intensity of rainfall and input from areas with severe soil leaching or undeveloped soils [27].

Direct measurements showed that the EC of the Beton Reservoir was $325 \mu \mathrm{S} / \mathrm{cm}$. The dissolved ions and minerals contained in it may come from the farmland (paddy and dry-cultivated fields) in the catchment and shrubs and runoff from around the walls of the reservoir. Beton Spring, as an entrance for water in the catchment, can carry large amounts of sediment that will accumulate in the reservoir, both as suspensions and bottom sediments. Because EC is not an observed parameter in the water quality standard, the EC levels obtained in this study cannot be categorized into within or exceeding a specific threshold.

\subsubsection{Total dissolved solids (TDS)}

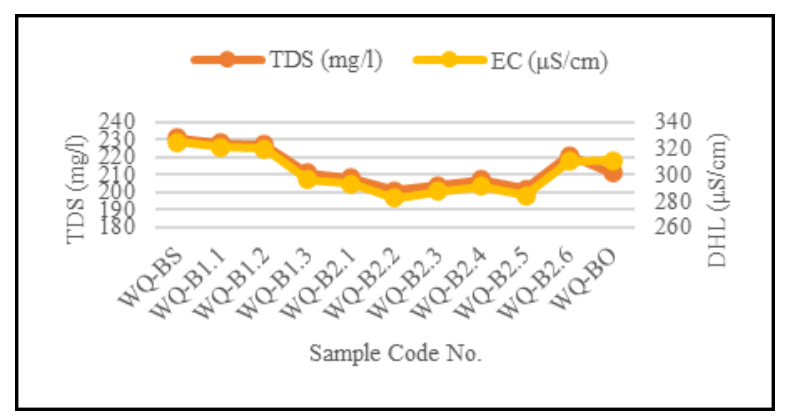

Fig. 4. Total dissolved solids and electrical conductivity of beton reservoir in rainy seasons

Overall, the TDS of the Beton Reservoir was 201 to $231 \mathrm{mg} \mathrm{L}^{-1}$ in the rainy season and $365 \mathrm{mg} \mathrm{L}^{-1}$ in the dry season. In this range, the TDS levels meet the quality standards for Class II water [30], with the upper threshold of $1000 \mathrm{mg} \mathrm{L}{ }^{-1}$. TDS is dependent on evaporation and water flushing. In general, TDS and EC values of the reservoir are always interrelated because they are both affected by the dissolution process of solids (Figure 4), and their non-linear correlation is controlled by salinity and the transported nutrients [31], as detected in the WQ-BO sample. Also, TDS is potentially associated with discharge, as evident from the TDS fluctuations that all followed these conditions.

\subsubsection{Total suspended solids (TSS)}

The TSS of the Beton Reservoir ranged from $17.5 \mathrm{mg} \mathrm{L}^{-1}$ to $93 \mathrm{mg} \mathrm{L}^{-1}$ in the rainy seasons and tended to hover around $20.8 \mathrm{mg} \mathrm{L}^{-1}$ in the dry season. In the water quality standard for Class II water, the maximum allowable TSS is $50 \mathrm{mg} \mathrm{L}^{-1}$. 
This number is meant to provide good protection against turbidity and excessive sedimentation [27]. As seen in Figure 5, the threshold for TSS had been exceeded at four points, namely WQ- B1.1, WQ-B1.2, WQ-B2.1, and WQ-B2.2.

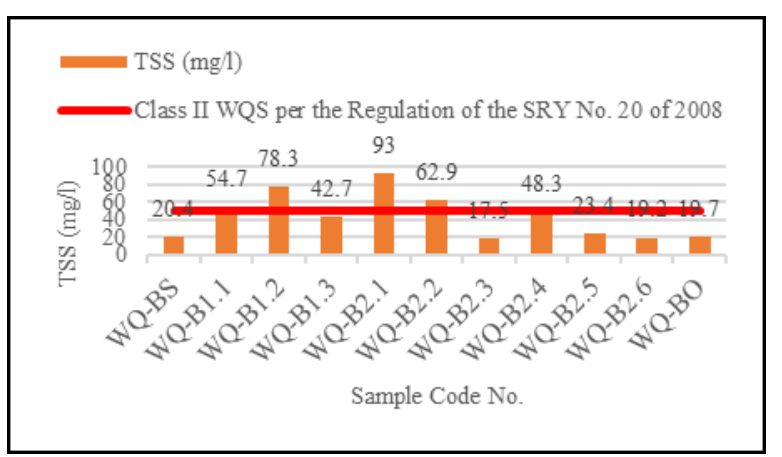

Fig. 5. Total suspended solids of beton reservoir in rainy seasons

Points WQ-B1.1 and WQ-B1.2 had shallow depths $(<1.5 \mathrm{~m})$ with thick deposits around them. In the dry season, the two points are dried up into an open land overgrown with wild plants, which are a sign of high deposits accumulating at the bottom of the reservoir during floods. WQ-B2.1 had the highest TSS because high water pressure around the Beton Bridge makes the materials transported from the upstream hit the reservoir walls and are deposited while the water continues to flow to the outlet of the reservoir. This flow lowers the TSS at other points to below $50 \mathrm{mg} \mathrm{L}^{-1}$, as apparent in the TSS at WQ-B2.2.

\subsection{5 $\mathrm{pH}$}

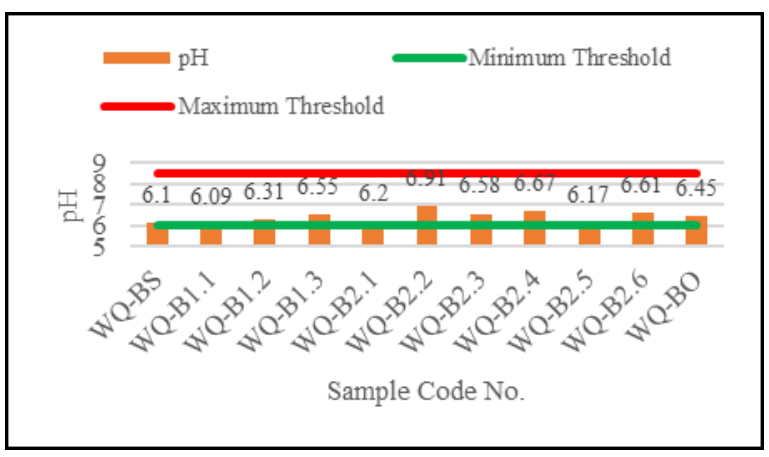

Fig. 6. Water $\mathrm{pH}$ of Beton reservoir in rainy seasons

Natural waters generally have a $\mathrm{pH}$ of 6 to 9 , but the optimum $\mathrm{pH}$ for aquatic organisms ranges from 6.5 to 8.5 [27]. The Beton Reservoir had a pH of 6.09-6.91 in the rainy season and 6.66 in the dry season. As presented in Figure 6, these figures meet the class II water quality standard, which is in the range of 6-8.5. In a terrain where limestone is the constituent rock, the water $\mathrm{pH}$ varies from 6.5 up to 8.9. Since the $\mathrm{pH}$ of the water body observed was not higher than $7, \mathrm{HCO}_{3}{ }^{-}$ions are dominant.

\subsubsection{Dissolved oxygen (DO)}

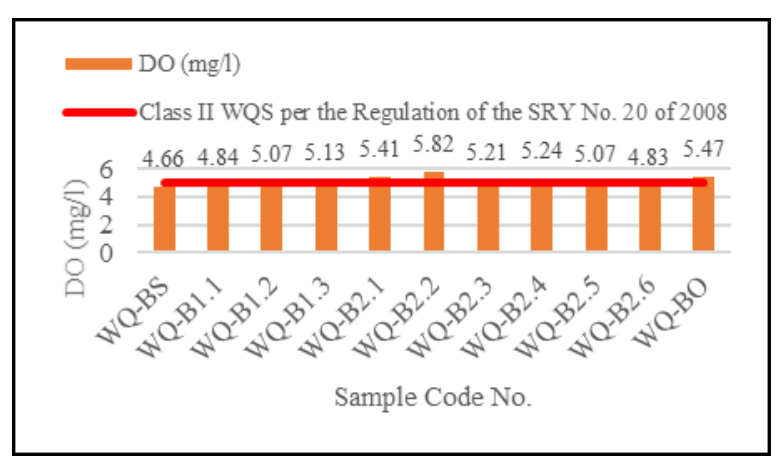

Fig. 7. Dissolved oxygen levels of beton reservoir in rainy seasons

The DO concentrations varied from 4.66 to $5.82 \mathrm{mg} \mathrm{L}^{-1}$ in the rainy season, whereas the composite DO in the dry season was $24.5 \mathrm{mg} \mathrm{L}^{-1}$. The optimal DO level is $7 \mathrm{mg} \mathrm{L}^{-1}$. Three samples had exceeded the upper threshold for DO, $5 \mathrm{mg} \mathrm{L}^{-1}$, namely WQ-BS, WQ-B1.1, and WQ-2.6 (Figure 7). The three points are located upstream and downstream of the reservoir, both of which have high TSS levels during the rainy season. Large water discharge increases TSS and makes the water turbid. High turbidity can disrupt photosynthesis and the life of aquatic organisms that produce DO.

\subsubsection{Biochemical oxygen demand (BOD)}

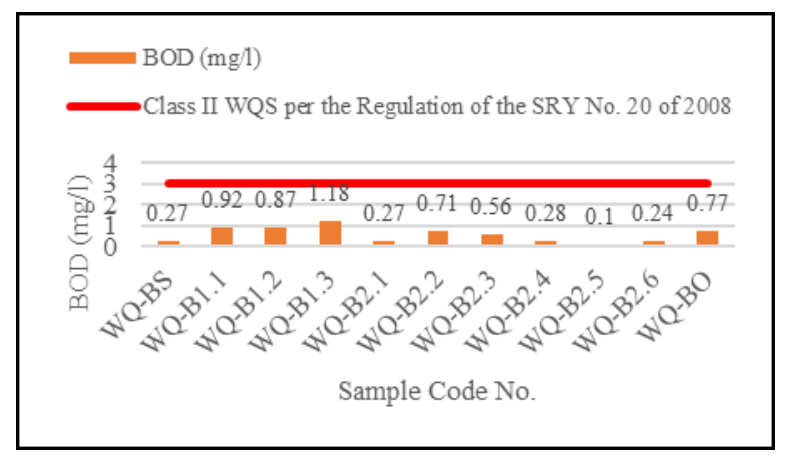

Fig. 8. Biological oxygen demands of beton reservoir in rainy seasons

In the Beton Reservoir, the BOD levels measured during the rainy season ranged between 0.1 and 1.18 $\mathrm{mg} \mathrm{L} \mathrm{L}^{-1}$. The BOD level in the dry season was not measured by the previous study referred to in this research [20]. Figure 8 shows that all BOD concentrations in the water did not exceed the applicable water quality standard; that is, $3 \mathrm{mg} \mathrm{L}^{-1}$. Natural waters usually have BOD levels in the range of 1 to $10 \mathrm{mg} \mathrm{L}^{-1}$, and a higher BOD often indicates the entry of waste from settlement areas and industrial estates [27]. Dissolved oxygen (DO) is a determinant of BOD: a higher DO always coincides with a lower BOD. In the event of heavy rainfall, aeration becomes more intense, and consequently, the DO level of a water body is higher than its BOD. 


\subsubsection{Chemical oxygen demand (COD)}

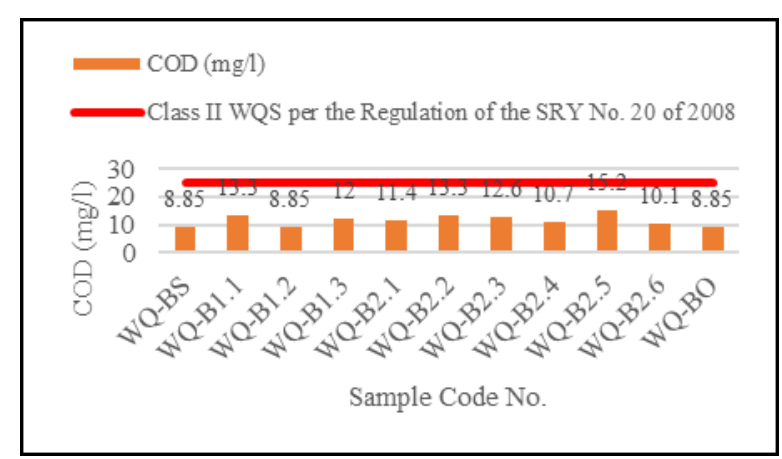

Fig. 9. Chemical oxygen demands of beton reservoir in rainy seasons

In waters, COD mainly comes from water channels in residential and industrial areas [25]. In the Beton Reservoir, the COD levels were in the range of 8.85$15.2 \mathrm{mg} \mathrm{L}^{-1}$, and the maximum level of allowable COD in the water quality standard used in this research is $25 \mathrm{mg} \mathrm{L}^{-1}$. Like BOD, there is no data on the COD of the reservoir observed in the dry season. COD variation of the water samples collected from the Beton Reservoir is presented in Figure 9. So far, there is no information on liquid waste disposed from the residential and industrial areas in the catchment, but solid waste like used plastics was found in the reservoir.

\subsubsection{Nitrate}

Agricultural activities in the catchment primarily shape nitrate concentrations in the reservoir. Fertilizers are known to be the most significant source of nitrogen pollution in water bodies. Based on interviews with farmers in Sawahombo and Sawahan Seropan, manure (organic) and chemical (inorganic) fertilizers were applied in the cultivation of local agricultural commodities. At the time of the research, both farmlands had been fertilized at the beginning of the cropping season and were awaiting second-phase of fertilization.

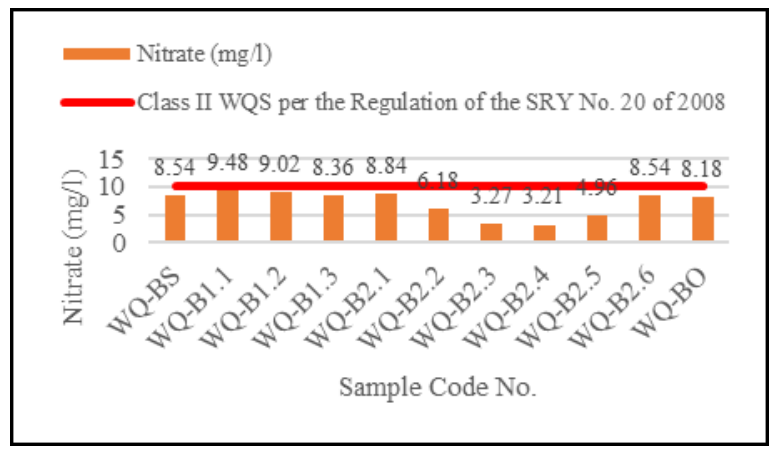

Fig. 10. Nitrate contents of beton reservoir in rainy seasons

Since nitrate is soluble in water, this nitrogen compound can exist in a long time and reach a long distance from its source. Therefore, it can enter the water body through leaching, soil erosion, and runoff [29]. In the rainy season, the variation in nitrate content (Figure 10) is influenced by various factors, including sedimentation and the sampling process at WQ-B2.2 WQ-B2.5. All water samples contained nitrates below the upper threshold set in the water quality standard, that is, $10 \mathrm{mg} \mathrm{L}^{-1}$.

\subsubsection{Total phosphate}

Measurements of the phosphate contents in dry and rainy seasons yielded a limit of detection (LOD), which was less than $0.09 \mathrm{mg} \mathrm{L}^{-1}$. Similar to nitrate, agricultural land in the catchment is believed to be the source of phosphate in the reservoir. Low phosphate content may be because (a) phosphorus content in manure or urea is generally lower than nitrogen [30, 31], (b) high phosphorus levels are rarely found in freshwater because vegetation actively absorbs phosphorus for growth [32], and (c) phosphorus can be easily removed from the water and bound to sediments [27].

\subsubsection{Total coliform}

In the rainy season, the total coliform of eight sampling points meets the quality standard, while the other three points (WQ-B1.3, WQ-B2.1, and WQ-B2.6) contained total coliform of $>2400 \mathrm{MPN} / 100 \mathrm{ml}$ (maximum laboratory detection limit) (Table 1). The total coliform in the dry season was $93 \mathrm{MPN} / 100 \mathrm{ml}$, indicating a significant increase in coliform bacteria in the rainy season. Coliform bacteria count increases as water depth decreases because these bacteria are aerobic and facultative anaerobic [27], as apparent in WQ-BO and WQ-B1.1-WQ-B1.3. Compared to the south of the bridge, these points are relatively shallow, creating access to oxygen for the growth of these bacteria. A high count of total coliform is thought to be the result of fish droppings from nearby ponds.

Table 1. Total coliform of beton reservoir in rainy seasons

\begin{tabular}{|c|c|c|}
\hline No. & Sample Code No. & $\begin{array}{c}\text { Total Coliform } \\
\text { (MPN/100 ml) }\end{array}$ \\
\hline $\begin{array}{c}\text { Class II WQS per the Regulation of } \\
\text { the SRY Governor No. 20 of 2008 }\end{array}$ & 5,000 \\
\hline 1 & WQ-BS & 460 \\
\hline 2 & WQ-B1.1 & 1100 \\
\hline 3 & WQ-B1.2 & 1100 \\
\hline 4 & WQ-B1.3 & $>2400$ \\
\hline 5 & WQ-B2.1 & $>2400$ \\
\hline 6 & WQ-B2.2 & 1100 \\
\hline 7 & WQ-B2.3 & 75 \\
\hline 8 & WQ-B2.4 & 43 \\
\hline 9 & WQ-B2.5 & $>2400$ \\
\hline 10 & WQ-B2.6 & 1100 \\
\hline 11 & WQ-BO & \\
\hline
\end{tabular}

\subsection{Total maximum daily loads (TMDLS) of beton reservoir}

The maximum amount of pollutants that the Beton Reservoir can receive must not exceed the Class II water quality standards for the same pollutants [21]. As a consideration, the examination of phosphate levels is constrained by the limit of detection of the 
parameter test equipment used so that in the TMDLs calculation, the phosphate levels of the entire Beton Reservoir were generalized and accordingly set at 0.09 $\mathrm{mg} \mathrm{L}^{-1}$. Similarly, the TMDL calculations for DO were also adjusted because the water quality standard does not require a maximum level but a minimum one. The TMDLs of the Beton Reservoir at the beginning of the rainy season are summarized in Table 2. TMDLs for TSS and nitrate were negative, meaning that the reservoir can no longer accommodate TSS and nitrate loads.

Table 2. The TMDL calculation results for beton reservoir

\begin{tabular}{|c|l|r|c|}
\hline No. & \multicolumn{1}{|c|}{ Parameters } & \multicolumn{1}{c|}{ Values } & Measurement Units \\
\hline 1 & TSS & -258.01 & ton/year \\
\hline 2 & DO & 76.74 & ton/year \\
\hline 3 & BOD & 33.73 & ton/year \\
\hline 4 & COD & 71.24 & ton/year \\
\hline 5 & Nitrate & -87.38 & ton/year \\
\hline 6 & Total Phosphate & 0.32 & ton/year \\
\hline
\end{tabular}

Spatially, the test results showed that the TSS levels of four sampling points had exceeded the water quality standard, while their nitrate contents were still below the maximum amount of its allowable presence in a Class II water. The average values of the two parameters at all observation points in the reservoir had not exceeded the standard ([Pa $\left.]_{\mathrm{STD}}\right)$. However, based on the accumulation of their mean concentrations and the load allocations for activities in the catchment, TSS and nitrate have exceeded the $[\mathrm{Pa}]_{\mathrm{STD}}$.

TMDL calculations also showed that the reservoir could still tolerate the DO levels, even though the water quality standard was exceeded at three sampling points, including the point of representation $[\mathrm{Pa}]_{\text {cat. }}$ It is because the sum of $[\mathrm{Pa}]_{i}$ and $[\mathrm{Pa}]_{\text {cat }}$ yielded a higher value than $[\mathrm{Pa}]_{\mathrm{STD}} \mathrm{DO}$, i.e., $>5 \mathrm{mg} \mathrm{L}^{-1}$ or $>5.000$ $\mathrm{mg} / \mathrm{m}^{3}$. Because the DO levels still met the pollutant load allocation of Beton Reservoir, the TMDL for this parameter was also fulfilled.

The amount of waste load and TMDL cannot be separated from natural conditions and human activities around the reservoir. High pollutant loads in the form of TSS and nitrate content are associated with the rainy season, which causes the water supply-as a transporting agent of pollution loads-to increase. During the interview, the respondents also explained that fertilizers were applied to agricultural land during that period (fertilization phase) so that nitrates (highly soluble in waters) would be transported along with the product of soil leaching and large amounts of water. The TMDL for TSS or nitrate is dependent on agricultural activities, similar to the TMDLs of Tambakboyo Reservoir and Merdada Lake [25, 33].

Morphometry and hydrological conditions also influence the final outcome of TMDL. Hydrologically, karst is dominated by conduit development that produces large water discharge during the rainy season, causing water to fill up the reservoir quickly and even overflow the capacity. Therefore, Beton Reservoir has an enormous accumulative discharge, namely $15016478.2 \mathrm{~m}^{3} /$ year. Large water volume and discharge lead to a high rate of water replacement, and this dynamic condition can disturb the balance of the reservoir water.

\section{Conclusions}

Beton Reservoir is classified as a small artificial lake with a volume of $22586.83 \mathrm{~m}^{3}$, a surface area of $198.58 \mathrm{~m}^{2}$, and an average depth of $1.21 \mathrm{~m}$. During the rainy season, the water released from this reservoir can reach $15016478.2 \mathrm{~m}^{3} \mathrm{yr}^{-1}$. Based on the Regulation of the SRY Governor No. 20 of 2008, TSS and DO have exceeded the Class II water quality. The total maximum daily loads (TMDLs) of the Beton Reservoir for TSS and nitrate are $-258.01 \mathrm{t} \mathrm{yr}^{-1}$ and $-87.38 \mathrm{t} \mathrm{yr}^{-1}$, respectively. At this state, both pollutants have exceeded the maximum amount of their allowable presence in a Class II water. Moreover, the accumulation of pollution loads originating from the agricultural activities in the catchment, combined with seasonal influence and the morphometry of the reservoir, no longer meets the water quality standard

Authors would like to thank Universitas Gadjah Mada for the financial assistance given through the Thesis Recognition Grant (Hibah Rekognisi Tugas Akhir) in the fiscal year of 2020. Our gratitude also extends to the head of the tourism management of Beton Reservoir and the Government of Umbulrejo Village, Ponjong District, Gunungkidul Regency, for facilitating the research.

\section{References}

1. D. Ford, P. Williams, Karst Hydrogeology and Geomorphology, John Wiley \& Sons Ltd, Chichester, (2007)

2. M. Widyastuti, A. Cahyadi, M.H.D. Sasongko, Hidrologi dan Hidrogeologi Karst, In: Pedoman Praktis Survei Terintegrasi Kawasan Karst, pp. 2063, Haryono E. (Eds.), Badan Penerbit Fakultas Geografi (BPFG) Universitas Gadjah Mada, Yogyakarta, (2016) (in Bahasa Indonesia)

3. N. Goldscheider, D. Drew, S. Worthington, Introduction, In: Methods in Karst Hydrogeology, N. Goldscheider, D. Drew, (Eds.), Taylor \& Francis, London, (2007)

4. W.B. White, Introduction to the Karst Hydrology of the Mammoth Cave Area, 1st ed. Springer Science+Business Media, New York, (1989)

5. T.M. Williams, D.M. Amatya, D.R. Hitchcock, E. Edwards, J Hydrol Eng. 19,2:428-438 (2014)

6. T.M. Reed, A.E. Fryar, G.M. Brion, J. W. Ward, Environ Earth Sci. 64:47-55 (2011)

7. R.N. Lerch. J Cave Karst Stud. 73,2:99-113 (2011)

8. T.W. Baker, C.G. Groves, Water Quality Impacts from Agricultural Land Use in Karst Drainage Basins of SW Kentucky and SW China, In: The Third Interagency Conference on Research in the Wathersheds, 103-16, 8-11 September, Estes Park, CO (2008)

9. H. Boyacioglu, M.N. Alpaslan, Environ Monit Assess. 146:411-21 (2008) 
10. E. Ongley, Y. Tao, Problems in Assessing Nonpoint Source Pollution in China: Links to Policy and Regulation, In: The Management of Water Quality and Irrigation Technologies, 1st ed, J. Albiac, A. Dinar, editors Earthscan, London \& Sterling, (2009)

11. Permen LH. Peraturan Menteri Negara Lingkungan Hidup Nomor 28 Tahun 2009 tentang Daya Tampung Beban Pencemaran Air Danau dan/atau Waduk. Jakarta, (2009) (in Bahasa Indonesia)

12. B. Machbub, J Sumber Daya Air. 6,2:129-44 (2010)

13. A. Cahyadi, M. Naufal, H. Fatchurohman, Uji Perunutan di Sistem Mataair Beton, Research Report, Kelompok Studi Karst Fakultas Geografi UGM, Yogyakarta, (2019) (in Bahasa Indonesia)

14. R.W.V. Bemmelen, The Geology of Indonesia. Vol. 1A: General Geology of Indonesia and Adjacent Archipelagoes, Government Printing Office, The Hague, (1949)

15. MacDonald, Partners, Greater YogyakartaGroundwater Resources Study. Volume 3C: Cave Survey, Directorate General of Water Resources Development Project (P2AT), Yogyakarta, (1984)

16. M. Naufal, Karakterisasi Perkembangan Akuifer Karst Gunung Sewu Melalui Analisis Master Recession Curve (MRC) (Studi Kasus Mataair Guntur dan Mataair Beton Kabupaten Gunungkidul), [Undergraduate Thesis]. Universitas Gadjah Mada, Yogyakarta, (2019) (in Bahasa Indonesia)

17. E. Haryono, T. N. Adji, Pengantar Geomorfologi dan Hidrologi Karst (Kelompok Studi Karst Fakultas Geografi UGM, Yogyakarta, 2004) (in Bahasa Indonesia)

18. Badan Standarisasi Nasional (BSN). Tata cara pengukuran debit aliran sungai dan saluran terbuka menggunakan alat ukur arus dan pelampung ICS, SNI 8066:2015, Jakarta, (2015) (in Bahasa Indonesia)

19. A. Hakanson, A Manual of Lake Morphometry Springer-Verlag Berlin Heidelberg, New York, (1981)

20. M. Widyastuti, I.A. Riyanto, M. Naufal, F. Ramadhan, K.S.A.A. Nisa, F. Firizqi, M.R. Irshabdillah. Studi Komparasi Potensi Sumberdaya Air Blok Panggang dan Blok Ponjong Kawasan Karst Gunungsewu untuk Mitigasi Bencana Kekeringan, Studi Kasus Kecamatan Purwosari dan Kecamatan Ponjong Kabupaten Gunungkidul, Research Report (not published, Universitas Gadjah Mada, Yogyakarta, (2020) (in Bahasa Indonesia)
21. DIY. Peraturan Gubernur DIY No. 20 Tahun 2008 tentang Baku Mutu Air di Provinsi Daerah Istimewa Yogyakarta, SR of Yogyakarta, (2008) (in Bahasa Indonesia)

22. Florida LAKEWATCH, A Beginner's Guide to Water Management-Water Clarity, 2nd ed. Florida LAKEWATCH, Florida, (2001)

23. M. Straškraba, J.G. Tundisi, Guidelines of Lake Management: Reservoir Water Quality Management, Volume 9, International Lake Environment Committee Foundation, Shiga, (1999)

24. A. Muhtadi, Yunasfi, M. Ma'rufi, A. Rizki, Oseano dan Limno di Indo. 2,2:49-63 (2017)

25. A. Ardinugroho, Kajian Daya Tampung Beban Pencemaran Air Embung Tambakboyo, Kecamatan Depok, Kabupaten Sleman, Undergraduate Thesis, Universitas Gadjah Mada, Yogyakarta, (2014) (in Bahasa Indonesia)

26. F. Tambunan, Daya Dukung Perairan Danau Lido Berkaitan dengan Pemanfaatannya untuk Kegiatan Budidaya Perikanan Sistem Keramba Jaring Apung, Undergraduate Thesis, Institur Pertanian Bogor, Bogor, (2010)

27. C.E. Boyd, Water Quality: An Introduction, 3rd ed. Springer Nature Switzerland, Cham, (2020)

28. J. Zheng, D. Han, River Basin Environments and Ecological Succession in Danjiangkou Reservoir, In: Tropical and Sub-Tropical Reservoir Limnology in China: Theory and Practice, B. P. Han, Z. Liu, editors, Springer, Dordrecht, (2012)

29. M.N. Khan, M. Mobin, Z.K. Abbas, S.A. Alamri, Fertilizers and Their Contaminants in Soils, Surface and Groundwater, In Encyclopedia of the Anthropocene, pp. 225-240, D. A. DellaSala, M. I. Goldstein, (Eds.) Elsevier, Oxford, (2018)

30. W. Safitri, R.S. Pujiati, P.T. Ningrum, Kandungan Nitrat pada Air Tanah di Sekitar Lahan Pertanian Padi, Palawija, dan Tembakau (Studi Di Desa Tanjungrejo Kecamatan Wuluhan Kabupaten Jember), Artikel Ilmiah Hasil Penelitian Mahasiswa Jember, Universitas Jember, (2014) (in Bahasa Indonesia)

31. A. Andayani, L. Sarido, AGRIFOR. XII,1:22-9 (2013)

32. A.C. Rizal, Y.N. Ihsan, E. Afrianto, L.P.S. Yuliadi, J Perikan dan Kelaut. VIII,2:7-16 (2017)

33. F.A. Rasyadi, Kajian Daya Tampung Beban Pencemaran Danau Merdada Kecamatan Batur, Kabupaten Banjarnegara, Undergraduate Thesis Universitas Gadjah Mada, Yogyakarta, (2016) (in Bahasa Indonesia) 